\title{
Fertility Concern in Finland and Russia: Economic Thinking and Ideal Family Size in the Rhetoric of Population Policies
}

\author{
ANNA-MARIA ISOLA, M.Soc.Sc, Researcher \\ Department of Social Policy, University of Helsinki, Finland
}

This article deals with fertility concern in Russian and Finnish population policies. The article points out that some commonly known discourses are persistently used as arguments in fertility-related population policies. In Finland, these include, for instance, discourses on "ageing nation" and "economic competitiveness". Russian policymakers use a "crisis discourse" that consists of three sub-discourses: "demographic crisis", "reproductive health in crisis" and "family crisis".

The Russian government implements pronatalist population policies, whereas Finnish authorities hesitate to use the term "population policy" because of its emphasis on reproductive rights on the one hand, and the negative associations of population policy on the other. Russia has both population and family programs, as well as a new law with a specifically pronatalist emphasis. Conversely, Finland uses family policy as a tool of population policy.

Keywords: fertility, fertility concern, population policy, rhetoric

\section{Introduction}

Both in Russia and Finland, government authorities have recently expressed explicit concern over decreasing population trends. In speaking of the issue, Finnish and Russian authorities who deal with population issues have constructed the problem of too-low fertility, but interestingly, the total fertility rate (TFR) is different in the two countries. TFR describes the completed fertility of a hypothetical generation. According to the total fertility rate, Finland is a low-fertility country, whereas in Russia, total fertility has fallen to the lowest-low level - a situation that resembles the one in Eastern and Southern Europe. Regardless of the differences between the two countries, Finnish and Russian authorities share the concern that their TFR is below replacement level. To reproduce a population, the TFR needs to be 2.1 or above. ${ }^{1}$

\footnotetext{
${ }^{1}$ Lowest-low fertility is defined as a level of total fertility at or below 1.3. Low fertility is below 2.1, which is the replacement level.
} 
In 2003, Russia's total fertility rate was 1.32 births per woman, and slightly but not significantly higher in 2004, at 1.34 (Rosstat 2004). Different interpretations have been given for the low fertility, but there is no established interpretation. For instance, Ivanov, Vichenvsky and Zakharov (2006) describe the current fertility situation as a normal phase of the modernization process (see also Thornton \& Philipov 2007), though some call Russia's population situation a "demographic crisis" (see Vichnevsky 1996) or "demographic catastrophe" or even call Russia a "dying nation" (Zakharov 1996; Rivkin-Fish 2006, 151).

Russia has gone through a rapid demographic transition from high to low fertility. Demographic changes in Finland have been more moderate (Therborn 2005), resulting in a situation where fertility is relatively high in the European context, but remains below replacement level. In 2006, Finland's population even increased by more than 20,000 (Statistics Finland), while in Russia the population decreased by nearly 800,000 from 2003 to 2004 (GGS, Contextual Database). Comparing Finland's fertility to other European countries, only Iceland, France, Ireland and Norway have total fertility rates that are higher (Eurostat). Compared with the United States, able to reproduce its population, Finland's fertility is low.

In this article I explore fertility concern in Finland and Russia. These two neighboring countries are characterized by low fertility and a rapidly ageing population, yet they are European countries with a very different history, culture and political atmosphere. They have faced the same societal challenges, but in fairly different contexts. How will these countries respond to the shared concern of low fertility?

Comparing two culturally and historically divergent countries also functions as a useful study method. As per Kakkuri-Knuutila (1998), taking distance from the familiar environment and considering a foreign context helps reveal phenomena and their special characteristics beyond conventional concepts. By contrasting Finland and Russia, we learn to see new aspects in both contexts.

I have chosen to use the term 'fertility concern', as this concern emerges in both countries as part of the population debate, including in population policy texts themselves. Simply, fertility concern refers to a fertility situation which, according to policymakers, is too low for particular reasons. "Fertility concern" has attained and maintained a prevalent position in the population discussions in both countries, as I will prove in this article. First, I describe the reasons and arguments that have been used to show that the concern over too-low fertility is real. Second, I study the explanations that are given by authorities for the low fertility. Finally, I will examine the extent to which there exist articulated and institutionalized fertility-related population policies in Russia and Finland, and what these policies are. More generally, I will examine the 
relationship between demographic trends and government attempts to control those trends in the fertility rhetoric.

I have chosen to concentrate mainly on two central elements in fertility-related population policies: ideal family size and economic thinking. I have excluded migration issues from this article, as they form an entity of their own. I first deal with Finnish data and then consult Russian findings. After analyzing each country separately, I will discuss similarities and differences in the population policy rhetoric of the two countries.

Two key concepts employed in this work are population policy and population rhetoric. I study the way that certain fertility rhetoric appears in population policies. Palonen (1979) states that everything in the world can be politicized. It is not about whether something is a political issue or not, it is about to what extent a particular issue has political dimension. As Palonen states, on the hand, politics can be well articulated and transparent, while on the other hand, it can be hazy and vague. When it comes to fertility, everyone is a policymaker, since individuals are capable of using their reproductive power through their bodies and reproductive decisions. Although women are at the very core of reproductive matters, I have focused on institutionalized population policies, and concentrated not on individuals at the grass-roots level but purely on the fertility policy that is practized by administrative entities. In the present work, this means significant exclusions. First, non-governmental entities have been mostly excluded from the data. Second, this also predefines the results, as the political process remains invisible. We see the outcome of this process in policy programs, but we do not see the individual opinions of citizens, politicians and non-governmental organizations, even though these opinions play an important role in the policymaking process.

Population policy is defined as the package of the intentions and measures which aim at influencing population development. These measures may have an impact on fertility, mortality, and migration. A blurred connection exists between social, housing, family, labor, health and population policy. Population policy can be divided roughly into two categories, into quantitative or qualitative population development. The latter includes the prevention of the social and economical marginalization of vulnerable groups. To put it simply, qualitative population development means that a greater number of healthy children are born, not a greater number of children born overall, whereas quantitative population development means a greater number of live-births. In this article I focus on quantitative population development.

Policies are compromises which reflect the prevailing ideological trends in societies. Trends, in turn, are mirrored in the public discussion on population growth and fertility (King 2002). From the state's point of view, in most cases the aim is population growth. But from the citizen's point of view, an individual makes a decision based on her or his 
personal choices. The starting point of population policy is the point at which the aspirations of the state and the individuals meet. This means that individuals want a certain number of children, and the state wants more children. Individuals want more children than they have in reality. The gap between the desired and actual number of children is where population policy can have an impact. Indeed, according to Bongaarts (1987), the desired number of children predicts the development of the actual number of children born.

To a great extent, low fertility can be seen as a political topic to which politicians react in different ways by offering various solutions. They may either encourage people to have more children by appealing to people's feelings of patriotism and responsibility, or they may offer economic or institutional support to families. States practice population policy both through institutional incentives, such as enabling parents to reconcile full-time work and family life by providing subsidized day-care services, and through monetary incentives, by providing child, maternal and parental benefits (Billari 2006; Prskawetz et al. 2006; Rønsen 2004). Roughly, states can be divided into countries whose policies are either oriented in institutional incentives or monetary incentives, although in most cases, the different types of incentives are used in combination.

\section{Fertility in population policy - data and methods}

In 2004, the Finnish Prime Minister Matti Vanhanen expressed a hope for developing population policy practices in Finland. According to him, fertility could have been higher, although it was already "moderately high" (Vanhanen 2004). Two years later, President Putin emphasized in his Victory Day speech that lowest-low fertility is a key social problem in Russia and has to be solved (Putin 2006). These statesmen's views show that fertility is at the forefront in both countries. Interestingly, Finland does not carry out population policy programs in a strict sense of the term; rather, its population policies are embedded in family policies. Family policies, in turn, form a set of various policies that influence both family and working life. The Finnish Prime Minister thus concentrated on arguing for the need for population policy measures, whereas Putin's speech was a prologue to forthcoming pronatalist changes in Russian legislation.

In addition to state authorities, non-governmental or civic organizations also take part in the population discussion. For instance, the Family Federation of Finland has asserted its position in family and population issues as a significant actor and is the main non-governmental force with an influence over population issues. Therefore, in 2004, it released a Population Policy Program with a particular focus on population growth. There is no corresponding organ in Russia's population discussion, but instead, women's organizations actively participate in the fertility discussion, emphasizing, for instance, women's right to adequate reproductive health. Also adoption organizations discuss fertility issues, in terms of social orphanage. The role of scientists is also powerful in the formation of Russian population policy. 
In this article, I employ data from official Russian and Finnish materials produced between 1995 and 2007. The Russian part consists of policy programs. In addition to these, legal documentation is included in the data in so far as it has relevance for the study questions. The policy programs have been produced by the ministries in charge of social affairs, health, labor and education. While they have been written in collaboration with certain Russian academic research centers, the materials have political, not academic overtones, and their writers remain largely unnamed within the texts.

The Finnish materials consist mainly of reports on population development by the Ministry for Social Affairs and Health. Contrary to the Russian materials, which practically work as policy tools on an operational and developmental level of administration, the Finnish reports include loose and non-mandatory policy recommendations. Thus, the Russian policy documents are hierarchically and operationally of a higher level than the Finnish documents ${ }^{2}$. Aarva, Shek and Rytkönen (2006) concluded in their research concerning health policy in Russia that Russian policy programs are not intended for lay people, but mainly for politicians and administrative authorities. In this sense, too, the Russian data differs from the Finnish population reports and accounts, which are directed at experts, politicians, as well as regular people. Whereas the Russian materials are political, the genre of the Finnish materials can be characterized as "expert" documents at the administrative level.

The method employed in this study is textual analysis, strongly inspired by the new rhetoric (Perelman \& Olbrecth-Tyteca 1971; Summa 1989), which is closely connected to the tradition of discourse analysis. The word 'rhetoric' means the ability to use language and understand the way people communicate, i.e. to manage communicative processes, use language for different purposes, or, in other words, the "competency to use language". In addition, rhetoric is a technique of persuasion. Persuasion, in turn, aims at pragmatically and emotionally approved truths. Thus, rhetoric is a type of reasoning that is based on interaction between the participants in a discussion (Summa 1989, 93).

In the theory of rhetoric, the concept of the argument is essential, as the purpose of persuasion is to reach a consensus among the audience or between the debaters. This consensus can be attained by arguing and reasoning. The content and formulation of the arguments and using references, in turn, are significant in reasoning. Generally speaking, rhetoric covers two aspects; first, the use of language as an act and as politics, for the purpose of changing the word, and second, as a tool of persuasion (Perelman \& Olbecht-Tyteca 1971; Summa 1989).

\footnotetext{
${ }^{2}$ The Finnish data contains only one programmatic text, the "Family Policy Program", which functions as a platform for policy making.
} 
Discourse, in turn, is defined by Summa as "collective consciousness", with a reference to Foucault. Summa continues that discourses are like an archive of statements that channel what is appropriate to say or not (Summa 1989,70). We see the link between discourse and rhetoric, when we understand that discourse constitutes a foundation for using language for persuasive and argumentative purposes. Thus, I perceive discourse as a tool-kit employed in rhetoric and in argumentation strategies.

Discourse is used when we aspire to render issues visible (Summa 1989, 74; Blommaert 2005). For instance, "demographic catastrophe" has become an integral part of Russia's population discussion, whereas Finnish population discourse is more polyphonic, and considerably biased towards ambivalence as to whether or not it is possible to influence people's reproductive decisions. As mentioned before, fertility-related discourse has been colored with the concern over the ageing of the population, including issues such as labor force, culture and reproductive health in the future.

In analyzing rhetoric I am not interested in real-life phenomena as such. What is really true and what is represented in facts and figures is relatively inessential in studying arguments and their content. What matters is the role of words and argumentative strategies within discourses.

\section{Finnish fertility is high in the European context - a starting point}

Soon after the Second World War, fertility in Finland spiked. This generation, born between 1946 and 1950, is referred to as the "large generation", i.e. baby-boomers. The same trend occurred in the United Kingdom, United States and in Australia, but lasted a little longer than in Finland. Unusually high fertility required societies to provide more education services, housing opportunities and finally, geriatric services, which, in addition to the financing of pensions, is a major issue in today's Finland.

After the 1950s, fertility decreased and reached a bottom in 1972, when the TFR was 1.5. Soon thereafter, the discourse of the "ageing society" began to appear in public discussions (Koskinen et al. 2007, 272). Despite forecasts that predict that Finland's population will keep growing until the year 2020, fertility concern has remained an important topic in Finnish population discussion, because after 2020, the growth will end, and the population count will enter a downturn.

"Compared with many European countries, the fertility rate in Finland is relatively high." (Finland: Family Federation of Finland, Population Policy Program 2004)

"A concern for the future wavers behind all thinking, and this must affect actual decisions. Therefore it is important that population policy issues are brought to the forefront in the social policy debate." (Finland: Report of the Family and Population Committee 1995) 
The extracts above illustrate the fertility situation in Finland. Almost without exception, Finnish population-related documents introduce the fertility issue by mentioning that "Finland has relatively high fertility in the European context". The way of introducing well-known Finnish discourses about having "high fertility in the European context" as well as the "concern for the future" amounts to "presumptions" (Perelman \& Olbrechts-Tyteca 1971) derived from the cultural archive of population-related statements, inserted before the texts themselves even begin to deliberate on fertility issues more profoundly.

Taking "relatively high fertility" as a normative starting point, and connecting the prevailing population situation to fertility concern, functions as a particular aspect of the argumentation process. Presenting familiar discourses as "presumptions" is a tool for sensitizing the audience for the topic at hand. The purpose of employing such "hegemonic discourses" is to reduce obstacles in communication which may derive from the experiences or passionate emotions of the audience (Perelman \& OlbrechtTyteca 1971). Fertility issues have been dealt with cautiously, because reproductive questions are sensitive by virtue of the fact that they belong to both the private and public spheres. But why is fertility such a big issue in Finland? Fertility is relatively high and the population will continue growing over the next ten to fifteen years. What is causing the fear about the future?

\section{An ageing nation and economic competition - an argument}

In this part I will examine the way that economic arguments are used in the discussion about fertility concern. Even though Finland's total fertility rate is below replacement level, it is relatively high in the European context. Thus, total fertility rate (TFR) is not an appropriate indicator for convincing a Finnish audience of the need for concern over too-low fertility. Authorities will need other arguments to persuade the greater audience that Finland must practice population policy measures to address the issues in the extracts, below. The dependency ratio ${ }^{3}$ suits this purpose, as it proves that fertility concern in Finland is justified:

"According to forecasts, the Finnish workforce will be the most aged of the European countries already in 2000, when the proportion of workers 45 years or older will account for more than 40 percent of the workforce."

"--Currently in Finland, there are on average 4.9 people of working age per every person aged 65 years or older. In 2020, the average is forecast to be 2.9, and in 2030 only 2.6. The same average in OECD-countries is forecast to be 3.8 in 2020." (Finland: Report of the Family and Population Committee 1995)

\footnotetext{
${ }^{3}$ The dependency ratio depicts the share of dependents (normally people under the age of 15 or over 65) in proportion to the productive part of the population. This ratio predicts the economic participation of productive people in paying for childcare and pensions.
} 
The above extracts show the development of the dependency ratio in Finland. Including the dependency ratio as part of the argument, Finnish population development suddenly appears in a totally different light, even when compared with other European countries, and even if the country's population will continue to grow until 2020. Using the dependency ratio reveals that not only fertility, but the future labor force is at the crux of the fertility concern. In the future, fewer and fewer Finns of working age will sustain an increasing number of pensioners. The retirement of the Finnish baby-boom generation is a sensitive topic. Thus, the Family Federation of Finland emphasizes in its Population Policy Program that "ageing does not mean becoming disabled. An ageing society is not an impaired society."

"The work of the Family and Population Committee has been shadowed by a concern over Finland's ability to cope with major future challenges, as the population is aging and the average birth rate has not for quite some time reached the level required to maintain or increase the total population count." (Finland: Report of the Family and Population Committee 1995)

As an argument for fertility concern, the dependency ratio makes sense for two reasons. First, it addresses the question of an ageing society and the impacts of ageing on social policy and pension expenditures in particular. This issue is connected to the discussion about the welfare state's ability to take care of its citizens. In this sense, the reproducing population is in a key position. To manage societies and economics, we need people.

"The plunging of the dependency ratio also results in a diminished ability of the country to carry out its social and socio-political responsibilities. Of specific concern is the declining number of the working-age population, as the population overall ages." (Finland: Family Federation of Finland, Population Policy Program 2004)

Implicitly, the Finnish materials tell a story of economic competitiveness and a concern about this competitiveness, also in the European context. A comparison with the United States makes sense, as the U.S. has been able to reproduce its population and greatly dominates global markets. European nations are a team that competes with the U.S. in global markets. Thus, in the background, there is a concern over fertility trends in Europe and a more general concern over European economic competitiveness in the future (See Fahey \& Speder 2004, 7).

\section{Third child - a solution?}

As pointed out above, there is a fertility concern, and the main reason is the fear about Finland's economic competitiveness. In the following, I will examine the ways in which state authorities interpret the reasons for low fertility and the policies they believe should be carried out to increase fertility rates. 
"A key group, as far as the birth rate is concerned, is home-centric families with three or more children. They account for 20 percent of all families with children, and the proportion of these families has grown somewhat over the last few years. There is quite a lot of potential for larger families already. The goal is that the proportion of families with three or more children would be 30 percent of all families with children. Currently, their proportion is approximately one-fifth." (Finland: Family Federation of Finland, Population Policy Program 2004)

Although Finland has not articulated clear pronatalist goals, the documents do flirt with population policy ideas that aim to increase the number of families with many children. In theory, authorities view the growing number of large families as a favorable state of affairs. As mentioned earlier, Finland does not actually execute population policy as such, but does carry out measures connected to population policy (Koskinen et al. 2007, 296) that are mainly embedded in family policies. Welfare state policies do include pronatalist measures, even though they do not exclusively target fertility growth (King 2002).

"Nowadays an increasing proportion of women are not going to have children. The number of women who will never have children of their own is expected to increase. On the other hand, those women who do give birth will on average have more children than before." (Report of the Family and Population Committee 1995)

The documents I examined show that having children has become polarized in Finland. The number of families with many children as well as those with no intention of having a child has grown. On account of this polarization of births, it becomes understandable that if anything could be done to improve the birth rate, while not being the state's official line, the best way to have an impact on fertility decisions is to identify appropriate tools addressed to three typical groups in Finland, i.e. familyoriented people, adaptive people and those who postpone birth.

The Finnish committee documents and policy programs offer a few methods for pursuing higher fertility. The first is to increase the number of families with three or more children. The second is to motivate adaptive people to have more children, and the third is to lower the child-bearing age among those who postpone birth. Adaptive people would, in appropriate circumstances, have more children. Appropriate circumstances here mean refers to the ability to reconcile work and family life. It also means the state providing a sufficient system of family benefits.

"In the beginning of the $21^{\text {st }}$ century, population development remains a current challenge as the population is aging and the birth rate is in decline. Starting a family happens at a later life stage, and fewer and fewer people are starting one. The prevailing lifestyle and values guiding the decision result in people delaying having children. When delayed for long, having children becomes more difficult, as fertility becomes lowered: thus, the declining number of births is also partly involuntary." (Finland: The Strategy of Family Policy 2003) 
One of the ways of influencing fertility is to lower the age of childbirth among women who may postpone childbirth until they are no longer capable of conceiving for physiological reasons. According to authorities, unintentional infertility could be decreased, but the way to do it remains unclear.

Interestingly, the authors of the committee papers and other documents follow, among other things, Hakim's (2000) preference theory on fertility, by adopting Hakim's categorization of three types of women. Hence, population policy texts are largely based on scientific research. The texts express favorable goals with regard to future trends, but remain superficial when it comes to identifying how, for instance, to impact these three types of women to have more children. Instead of clear policy recommendations, the authors instead offer descriptions of fertility trends and fertility effects.

\section{Family policy and institutional incentives as population policy}

"Population issues have created clear challenges for both national and European Union decision-makers. The issue behind the population policy debate has largely to do with how to retain the attained level of wellbeing while keeping momentum in the economy. Nations therefore use population policy to drive their own national interests." (Finland: Should fertility be enhanced? 2005)

Finnish policy makers are between the devil and the deep blue sea in two senses. First, the Finnish texts deliberate on the ethical question of fertility enhancement and globally limited natural resources, including global discourse on the population explosion. In the end, global questions are largely ignored as state authorities concentrate on national issues instead. The economic competitiveness of Finland and Europe emerge strongly in the texts, defying the global context of population development (see Koivusalo 1994).

Secondly, the term 'population policy' still carries an echo of its past stigma. Reports and committee papers often ask whether the task of the state is to try to influence fertility at all. Finnish population-related texts strongly emphasize reproductive rights, partially because of history's lessons but also because of ideals regarding the freedom of the individual.

"Population policy as such has a dubious ring to it, amongst experts and citizens alike. Who would not be aware of population policy "resolutions" in Nazi Germany, evacuations during Stalin's time, or the Chinese one-child policy. However, the lowered birth rates and fertility in the Western world and particularly in Europe have brought back the population policy debate." (Finland: Should fertility be enhanced? 2005)

Finland has no pronatalist goals. Here, pronatalist means attempting to influence the welfare and the health of the family while aiming directly at improved fertility 
rates. Increased fertility is a demographic bonus of implemented family policies, not a manifested goal (see also Hiilamo 2002, 154). This applies also to Finland, as the following extract points out:

"With regard to the birth rate, the current family policy in Finland can therefore be described as not having increasing the birth rate as a specific goal. A growing birth rate can be viewed more as a possible consequence of family policy strategy, which development should anyhow be in the interests of both families and the society at large." (Finland: Should fertility be enhanced? 2005)

Even then, Finnish authorities doubt the impact of economic incentives within family policy, claiming that adequate evidence of the implications of economic incentives does not exist. No doubt, the significance of economic incentives is conceded to some extent, but they are not emphasized. Instead, lifting living conditions of families, and improving gender and class equality are seen as an indirect instrument for promoting fertility, whereas flexible reconciliation of either work or studies and family life is emphasized in particular as a direct measure. According to Pajama $(2005,80)$, parents aged between 20 and 25 express a need for improvements in maternal allowances and study grants, whereas older families support improvements in working life, for instance, by reducing short-term jobs.

\section{From crisis to crisis - demography, families and reproductive health in crisis in Russia: starting points}

Russia has witnessed a steady population decline, particularly a few years following the fall of the Soviet Union (GGS, Contextual Database). Today, the situation is characterized by the high mortality typical of developing countries and the low fertility typical of the industrialized world. Russia has experienced the depopulation process later, but more explosively than Western Europe (Zakharov 1999; Lallukka 2003; Therborn 2005).

In their recent synthesis of Russian population policy, Ivanov, Vichnevsky \& Zakharov (2006) examined Russian fertility trends and the government's responses to the changing population development. Communism evoked the picture of a society where fertility remains high. It was thought that when the proletariat ruled, living conditions would be so convenient that all children would be welcome. In Soviet Russia, rapid population growth took place in the 1920s, and slowed down in the 1930s, and again in the 1970s, when Russian politicians became increasingly alarmed over decreasing fertility. In the 1930s, the government conducted family policy reforms by enacting a subsidy system, e.g. for mothers with many children. The state also implemented a "politics of restrictions and denials" (Ivanov, Vichnevsky \& Zakharov 2006), by outlawing abortion until 1955 and making divorce more difficult to obtain. After Stalinism, population growth was mainly promoted through social and ideological support. Scholars refer to the population policy introduced in the 1970's as "fertility 
policy" because of its pronatalist emphasis. In the 1980s, fertility increased by as much as 20 percent by age cohort, but this reflected changes in the timing of having children, not any total growth in the birth rate as measured in completed fertility rates. The latest period of low fertility in Russia began in 1988 (Rosstat 2004).

Women's groups still recently blamed the Russian government for ignoring fertility issues. They claimed that though authorities are aware of the decreasing birth rate, they allot nothing extra for population-related costs (Malysheva 2005). According to women's organizations, this meant that the fact of low fertility is alive only in political papers but not on any executive agendas. Yet things have changed and fertility policies have been established.

"The demographic situation in Russia is characterized by a decreasing birthrate, which has decreased within 5 years from 13.4 (per 1,000 people) in 1990 to 9.3 (per 1,000 people) in 1995. The average number of newborns in 1990 was 55.3 (per 1,000 15-49-year-old women), but in 1995 this figure was 35.3, meaning that during 1990-1995, the birth rate has decreased by 36.1\%." (Russia: Safe Motherhood 1997)

Most Russian programs, including the program for Safe Motherhood from 1997, emphasize that the demographic situation related to low fertility is a key problem in Russian society. The solution requires constitutive measures. Solutions to major social problems are sought through target programs (tselevaja programma) that contain measures related to Russia's ecological, social, cultural and national affairs. Measures included in such programs are partially or completely financed from the federal budget.

In Russia, not only the fertility concern but also a concern over the reproductive health of women and young people as well as a concern over the disintegration of family values, emerge in policy texts. A number of family experts and politicians, including President Putin, have expressed a concern over the "family crisis", where the family as a basic unit of society is losing its status and, as a consequence, the welfare of the families has declined, and furthermore, the number of social orphans has increased (Skortsova 2007; Isola 2008a). In the following extract, the family crisis is expressed through children, youth and changing parental culture:

"The general role of governmental social policy is to combat negative tendencies in the status of children in Russian society." (Russia: Federal Child Policy)

"Nowadays it's a vital issue for a family to have enough time to rear children. Parents have less and less time to spend with their children because of additional work required to make a living. Lack of time is also caused by the fact that a lot of work that was previously done by the service sector is now being done within families." (Russia: Federal Child Policy) 
Reproductive health, in turn, implies that people are able to have a satisfying and safe sex life and have the opportunity to decide whether, when, how often, and with whom to reproduce. It also means that couples have access to appropriate health-care services and safe follow-up during pregnancy or childbirth. Russian authorities document that the reproductive health of women of fertile age and young people is a special problem. Indicators show that the future of reproductive health in Russia does not look promising due to society's inability to offer adequate health-care services and thus prevent maternal mortality:

"One of the major characteristics that reveal the quality of medical care for women and their state of health is maternal mortality. In Russia, maternal mortality is rather frequent and it isn't decreasing. This index is approximately 2.5 times bigger that the same in Europe. The main reasons for maternal mortality are abortion, bleeding and toxicosis. But, according to scientists, twothirds of these cases could be prevented." (Russia: Safe Motherhood 1997)

But why is depopulation an actual problem? Is it just the fear of being a "dying nation", or is the real issue one of economic competitiveness, like it is in Finland? Interestingly, Russian authorities do not provide any explanation for why depopulation is one of the most important problems in Russia, while statistics to prove that the population development is alarming proliferate. To prove this frightening situation, state authorities employ three common sub-discourses, which can be bundled together into a single "crisis discourse", composed of demographic crisis, family crisis and the crisis of reproductive health of the population.

\section{Economic crisis in the background - the explanation}

Russia's poor socio-economic circumstances contribute to problems in people's health. Unsatisfactory reproductive health, in turn, causes a drop in fertility. Authorities argue that, on the one hand, people's poor health stems from an institutional deficit in the healthcare system. On the other hand, the poor health situation originates in people's indifferent attitudes toward issues of health. Whatever the case is, the result is a vicious circle from which is hard to emerge and solve the problems. Thus, concerns over family values and reproductive health are intertwined with fertility concern. The poor reproductive health of people and socio-economic issues are regularly mentioned as the causes of low fertility:

"The severe conditions of country's development reveal themselves particularly in high rates of illness and death, low birth rate, mothers' and children's health conditions, poor nutrition, especially among the poorest level of the population, and also in increasing social differentiation." (Russia: Health Program)

The documents express concern over the social and financial difficulties in society and their negative effects on family institutions. The same fear exists in all programs. To make sure that children receive a complete and satisfactory (polnotsennaja) upbringing of children, Russia needs to strengthen the status of the family as a basic 
unit in society, improve the economic conditions of families and encourage parents to assume responsibility for their offspring. Otherwise, the number of youth with severe problems will increase. This would translate into accumulating problems in future population development, as the next extract explains:

"Nowadays Russia's social and economic problems have weakened the institution of the family and its influence on child rearing. As a result, the number of homeless and neglected children has increased, and it has led to extended alcohol and drug abuse among teenagers and children, and as a further consequence, an increasing amount of crime. During the last 10 years, the number of drugaddicted young people has increased ten-fold". (Russia: Russia's Children)

Difficulties in the social and economic life of Russian families mean not only difficulties in providing proper nutrition or accessing satisfactory health care, but accumulate into other problems in the long run, narrowing the possibilities of taking care of oneself and one's children. The logic of the concern over socio-economic difficulties is that little by little, misery lowers "health culture" (see Larivaara 2007; Rivkin-Fish 2005), "parental culture" and "moral culture". Furthermore, the decreasing educational potential of parents, for instance, maintains low fertility rates, because people in uncertain circumstances are not willing to have children or, according to rhetoric, they simply are not capable of conceiving as a result of their poor state of reproductive health. According to the Russian texts, a decreasing number of healthy newborns results in a decreasing number of healthy youth, and finally, a decreasing number of adults capable of getting pregnant.

Russian authorities seem to adopt both cultural and structural determinants when they explain Russia's low fertility. The structural approach emphasizes economic factors, which play a large role in fertility rhetoric at the micro level. The cultural approach highlights the ideational change in values and attitudes (see Vitali et al. 2007), which can be particularly be perceived in the discourse on the family crisis.

\section{Second child is the solution - pronatalist policies with economic incentives}

"In the area of fertility, the following aims were defined: generating a social and personal value system that is oriented to the model of a family with two or more children". (Russia: Population Concept)

When it comes to childbearing age, Russia still maintains the tradition of marrying young, a common trait in Eastern Europe (Therborn 2005, 183), and couples usually give birth in marriage, in approximately in seven cases out of ten (GGS, Contextual Database). Studies concerning fertility and family reveal that the completed family size is far from the aspired numbers of children; the desired number is 2.3 children in St. Petersburg (Kesseli et al. 2005). 
"Low incomes are centered on families with many children; young families with small children; disabled children; single-parent families; and families with unemployed parents. According to population statistics, families with under-age children are poor more often". (Federal Child Policy)

Attitudes towards families with many children are somewhat twofold and even ambivalent in Russia. Large families are mentioned as a population policy goal, but the same group is simultaneously categorized as at-risk families that need special support to manage everyday life. Russia has a long tradition rewarding heroic mothers with many children. In 1999, the government established a target program for large families. This program includes e.g. additional benefits, discounts on day care and public transport, to assist families in their everyday lives because of their inability to afford even basic commodities.

In particular, many women in St. Petersburg expressed that, in reality, having three children in Russia is a lot, "almost too much" (Rotkirch \& Kesseli 2007). Taking into consideration both the opinion of lay people and the increased social and economic risks of families with many children that emerge from the data, the goal of increasing the number of families with three children is more ambiguous than realistic.

The media has been assigned the task of educating Russian people in health and family issues. The aim is to promote family values, parenting and health cultures which, in the long run, can have a positive impact on fertility trends. In this connection, focus is on youth particularly, as youth is said to be the hope of the future, even though Russian youth has at times been seen as a "lost generation" (Pilkington 1994), or its moral has been seen as having degenerated (Isola 2008b).

"The following are proposed to be relayed and published: regular television and radio programs on the problematic issues of family planning, organizing the dissemination of video clips and videos for different groups of the population, publishing and disseminating family planning-related printed materials (leaflets, brochures, posters)." (Family Planning Program 2002)

As in Finland, family benefits in Russia are universal ${ }^{4}$. Changes in laws indicate that a transition towards pronatalism has taken place in Russian population policy. As a consequence of Putin's rhetoric and his expression of concern over Russia's lowestlow fertility, a new law entitled "Maternity capital" was established in early 2007. The

\footnotetext{
${ }^{4}$ Family benefits in Russia consist of the following: maternity grant for pregnancy and childbirth (onetime transfer of 300 roubles); maternity grant (one-time transfer of 6,000 roubles); parental allowance (700 roubles monthly up to $1 \frac{1}{2}$ years) to the care-taker parent; child allowance (100 roubles monthly). In Finland, the state provides a maternity grant (140 EUR); maternity (105 workdays), paternity (18 days) and parental (158 workdays) allowances; child benefit (100-172 EUR depending on the number of children; child home-care allowances (basic allowance + supplement)
} 
law guarantees a transfer of 250,000 roubles especially to mothers, who give birth to a second or third child, but not for the first one. This maternity capital is intended for improving housing conditions; the sum can be used for purchasing an apartment, educating a child, or for the mother's insurance fees. The new law contains the hidden idea of the ideal family having a minimum of two children.

The maternity capital is a concrete outcome of the fertility rhetoric discussed in 2000. It points to the pragmatist, traditionalist approach policymakers have taken in their population policies. The pragmatic part of the law is that the transfer is addressed only for the second or third child. On the one hand, it would be unrealistic to aim for three children in a country, where almost all families have only one child. On the other hand, economic support for the first child would be wasting money, as almost all families have one child. Policymakers also take a traditionalist view, using as their normative starting point the "ideal" family, composed of a mother, a father and two children. Though the law addresses supporting women's status in society, it simultaneously contains the message that women's task is to reproduce.

According to Communist doctrine, the task of the state was to motivate and assist women to fulfill their motherhood task. However, both working long days and taking care of the family led women to assume a double burden (Zdravomyslova 1996; Rotkirch 2000; Caiazza 2002). Yet Communist society, without a doubt, assumed shared responsibility of these children by providing a day-care system. Today, governments and municipalities still provide 90 percent of day-care services, but for a fee, except from families with many children or single parents, who receive special subventions. According to the law, the state must ensure accessible day care to all children. In the maternity capital law, the focus is on women's position in society; the new transfers are usually paid to mothers, not to fathers. The logic of the improved maternal benefits is that by improving families' socio-economic circumstances, fertility rates will increase indirectly.

A pronatalist emphasis is not a brand-new idea within Russian population policy, as mentioned previously. Researchers refer to the population policy introduced in the 1970s as a "fertility policy", owing to its pronatalist emphasis. The future will show what implications recent measures will have.

\section{Discussion}

Regardless of the factual statistical divergence in fertility rates between Russia and Finland, messages in the policy and "expert" texts are convergent. Commonly-known discourses are used as presumptions in both countries. In Russia, the audience is expected to be familiar with the discourse of "demographic catastrophe", "family crisis" and "reproductive health crisis", while in Finland the discourse of "ageing nation" and the concept of the dependency ratio are employed as arguments for the fertility concern. 
In Russia, the crisis discourse derives from the economic crisis that took place after the fall of the Soviet Union and that can be considered a root cause of all of the other crises. Thus, Russian policy programs focus on the individual, at a micro level, and largely imply that low fertility is a consequence of the poor socio-economic situation of its citizens, yet individuals are also obligated to take care of themselves. The policy texts reveal that, according to Russian authorities, improving living conditions increases fertility rates, and that economic incentives work for this purpose. Russian authorities do not explain why depopulation is a problem from the perspective of the state. The larger concern for the Russian nation-state itself could be at the root of this, as a target program for the "Russian language" was established two years ago. It drops the hint that Russia could fear for its linguistic and cultural standing globally.

By contrast, Finnish authorities create a discourse of economic competitiveness when giving reasons for the fertility concern. They focus on the macro level, on the national economy. In this rhetoric, the dependency ratio plays a major role in the argumentation process. When fewer children are born, the dependency ratio is impaired, and this, in turn, causes possible problems in the national economy.

What, then, is being done to improve fertility situation in each country? In their texts, authorities in both countries articulate the need for a population policy both explicitly and implicitly, yet Finland and Russia are once again in a different place in terms of institutionalized population policies. Among other Eastern European countries that have undergone economic and societal transition, Russian policymakers have chosen the way of economic incentives in fertility policies. Finland, on the other hand, implements empowering policies, and does not focus merely on economic incentives but relies largely on institutional arrangements that make it easier to combine work and family life and that also advance gender equality.

The analyzed texts show that Finnish authorities hesitate to use the word "population policy" because of its perceived negative connotations from the Second World War and Finnish collaboration with the Nazis. ${ }^{5}$ Thus, reproductive rights are at the forefront of population policy. The texts contain both arguments on behalf of population policy but also counter-arguments from the perspective of reproductive rights. This may partially explain why "population policy" is hidden in Finland, and instead, family policy is used as a tool of population policy. The way this is formulated is that "population increase is a possible outcome of family policies". By contrast, Russian policymakers explicitly speak of population policy. Russia has not only set down population programs but also conducts pronatalist policies.

\footnotetext{
${ }^{5}$ When it comes to racist and eugenist ideas, Russia has a dead weight of its own. Ruben Callego (2006), for instance, has written an autobiography about his childhood as an ashamed and disabled child, who was sent to a state orphanage where disabled children were discriminated against in many activities.
} 
Reproductive rights and questions such as "is it generally possible for authorities to influence people's reproductive decisions" are emphasized in Finnish fertility debate. This theme emerges in other Western societies, too (Caldwell et al. 2002), and appears particularly when juxtaposing the population policies of Finland and Russia. The theme of reproductive rights is absent in Russian fertility rhetoric in terms of reproductive decision making. ${ }^{6}$ In their article dealing with Russian health policy programs, Aarva \& Rytkönen \& Shek (2006) also illuminate this phenomenon by explaining that the idea of individualism does not exist as powerfully in Soviet ideology as it exists in Western countries.

The Finnish texts emphasize the autonomy of the citizen in reproductive matters, whereas the Russian texts call for the responsibility of citizens to take care of their lives and the lives of their offspring and finally, to take care of the Russian nation-state. Thus, Russian citizens, to a greater extent than Finnish ones, are objects of policymaking, and mediadisseminated propaganda is used as a tool to educate people. Hence, Russian fertilityrelated population policies simultaneously include a value-based discourse about families, education, moral and health matters, and create related norms through such discourse. For instance, addressing large, one-time transfers to families with two or more children creates the norm of a nuclear family with two children. Consequently, Russian people tell an anecdote about today's Russian women, who faced an awkward dilemma: how to give to birth to the second child without having the first one (Botev 2007).

Interestingly, the theme of large families is somewhat ambivalent in both countries, but in Russia in particular. Finland has not identified targets in fertility development, whereas Russia has stated that its goal is to increase the number of families with two or three children. To improve fertility rates generally, Russia primarily needs more families with two children, but Finland has to increase the number of families with three or more children.

Why could the goal of three children not be a well-defined population policy goal in both countries? In Russia, the goal of three children is unrealistic for economic reasons, because of insufficient family income, as well as for issues of reproductive health. Particularly families with many children live in limited circumstances. In Russia, 80 percent of people lived below the poverty line at the time of the economic crisis in 1992 and 1993 (World Bank 2005). In Finland, on the other hand, ideological reasons related to reproductive rights forestall the establishment of a particular fertility objective, such as increasing the proportion of large families. The task of the state is to make it possible for its citizens to follow their aspirations.

\footnotetext{
${ }^{6}$ The Russian discussion on reproductive rights deals more with women's right to access adequate reproductive health-care services than on reproductive rights as such.
} 
Finally, this article gives rise to an interesting question about the standing of demographers in the field of population policy, as the texts from both countries quote the findings of demographers. The Finnish texts in particular are broadly based on demography as science, whereas the value-related language that belongs in the realm of politics is almost invisible. This may result in a situation where population policy texts are merely descriptions of population trends, not attempts or proposals to create a concrete package of policies that can promote the aspirations of the state and the individual.

\section{Data}

\section{Finland:}

Perhe- ja väestötoimikunnan mietintö. Sosiaali- ja terveysministeriö 1995:4. [Report of the Family and Population Committee]

Perhepoliittinen strategia 2003. Linjauksia ja taustoja perhepolitiikan kehittämiseen. Sosiaali- ja terveysministeriö. Helsinki. [The Strategy of Family Policy]

Väestöliiton väestöpoliittinen ohjelma 2004. Väestöliitto, Helsinki. [Family Federation of Finland, Population Policy Program]

Hyvä yhteiskunta kaikenikäisille. Valtioneuvoston tulevaisuusselonteko väestökehityksestä, väestöpolitiikasta ja ikärakenteen muutokseen varautumisesta. 2004

Väestökehitykseen vaikuttaminen - tulisiko syntyvyyttä ja maahanmuuttoa lisätä? Tulevaisuusselonteon liiteraportti 3. Valtioneuvoston kanslian julkaisusarja 31/2004. [Should fertility be enhanced?]

Vanhanen, Matti (2006) Väestökehitys ja väestöpolitiikka ovat tärkeitä aiheita. Väestöpoliittinen tulevaisuusfoorumi 1.10.2004

\section{Russia:}

Fereraljny zakon. O gosudarstvennyh posobijah grazhdanam, imejushsim detej. 1995

O dopolniteljnyh garantijah po sotsialnoj podderzhke -sirot i detej, ostavshihsja bez popechenija roditelej. 1996

Federalnajnaja tselevaja programma "Bezopasnoe materinstvo" na 1998-200o gody. 1997. [Safe Motherhood 1997]

Federaljnaja tselevaja programma "Planirovanie cemji na 1998-2000. 1997 [Family Planning Program]

Federaljny zakon. O gosudarstvennoj podderzhke mnogodetnyh semej 1999.

O tselevoj medico-sotsialnoj programme Sankt-Peterburga "Deti-invalidy"1999“"

Osnovyh napravlenij gosudarstvennoj sotsialjnoj politiki po uluchsheniju polozhenija detej v Rossijskoj federatsii do 2000 goda. [Federal Child Policy]

O tselevoj programme Sankt-Peterburga "Molodezhi - dostuphoe zhilje" 2001

O merah po ulucheniju reproduktivnogo zdorovja naselenija Rossijskoj federatsii. 2002 
O vnesenii izmenij I dopolnenij v zakon Sankt-Peterburga. O tselevoj programme Sankt-Peterburga "Deti-siroty" na 2002-2004 gody. 2003

Ob utverzhdenii otraslevoj programmy "Ohrana i ukreplenie zdorovja xdorovyh na 2003-2010. 2003 [Health Program]

Fereraljny zakon. O vnecenii izmennii v otdelny zakonnodateljnye akty Rossijskoj federatsii v chasti gosudarstvennoj podderzhki grazhdan, imejushsih detej 2006.

Fereraljny zakon. O dopolnitelnyh merah gosudarstvennoj podderzhki semej, imejushsih detej 2006.

O kontseptsii demograficheskogo razvitija Rossijskoj Federatsii na period na 2015 goda. [ Population Concept]

O federaljnoj tseleoj programme "Russkij jazyk (2006-2010 gody)

\section{References}

Aarva, Pauliina \& Shek, Olga \& Rytkönen, Marja. 2006. Venäjän terveyspolitiikka muutoksessa. Yksilön asema ja tehtävät terveyden edistämisessä vuosien 1988, 1993, 1997, 2000 ja 2003 terveyspoliittisissa asiakirjoissa. Sosiaalilääketieteellinen aikakauslehti 43, 88-100.

Billari, Fransesco C. 2006. Between policy-maker awareness and policy responses: lowest-low fertility in Italy. Entre Nous. The European magazine for sexual and reproductive health. WHO 64, 22-23.

Bongaarts, John. 1987. Family demography methods and their application. Oxford: Oxford University Press.

Botev, Nikolai. 2007. Could petro-rubles help in raising Russia's fertility? Paper presented at the International conference Can policies enhance fertility? Vienna, 6.-7. December 2007.

Blommaert, Jan. 2005. Discourse. Key topics in sociolinguistics. Cambridge: Cambridge University Press.

Caiazza, Amy. 2002. Mothers and soldiers. Gender, citizenship, and civil society in contemporary Russia. New York: Routledge.

Caldwell, John C \& Caldwell, Pat \& McDonald, Peter. 2002. Policy responces to low fertility and its consequences: a global survey. Journal of population research, 19 (1).

Eurostat. Population and social conditions. Available on Internet: http://epp.eurostat. ec.europa.eu/portal/

Fahey, Tony \& Spedér, Zsolt. 2004. Fertility and family issues in an enlarged Europe. European Foundation for the Improvement of Living and Working Conditions.

Gallego, Ruben. 2006. Mustaa valkoisella. Turku: Kustannusosakeyhtiö Sammakko.

GGS, Gender and Generations Contextual Database. Available on Internet http://www. demog.mpg.de

Isola, Anna-Maria. 2008a. Ritorika semei riska. In: Rotkirch, Anna \& Zdravomyslova, Elena (eds.): Novyj byt. St. Petersburg: European University Press

Isola, Anna-Maria. 2008b. Nuoriso ja Venäjän tulevaisuus. Terveyshuoli osana Venäjän alhaisen syntyvyyden retoriikkaa. Unpublished manuscript.

Ivanov, Serguey \& Vichnevsky, Anatoly \& Zakharov, Sergei. 2006. Population Policy 
in Russia. In: Caselli, Graziella \& Vallin, Jacques \& Wunsch, Guillaume (eds.) Demography. Analysis and Synthesis. New York: Elsevier, 407-433.

Kakkuri-Knuutila, Marja-Leena. 1998. Argumentti ja kritiikki: lukemisen, keskustelun ja vakuuttamisen taidot. Helsinki: Gaudeamus.

Kesseli, Katja \& Regushevskaya, Elena \& Doubikuaytis, Tatyana \& Kirichenko, Svetlana \& Rotkirch, Anna \& Haavio-Mannila, Elina \& Kuznetsova, Olga \& Hemminki, Elina and REFER group (2005) Reproductive Health and Fertility in St. Petersburg 2004: Report on a survey of 18-44 year old women in 2004 / Репродуктивное здоровье и фертилность в Санкт-Петербурге. Working papers 60, Department of Sociology, University of Helsinki.

Hakim, C. 2000. Work-lifestyle choices in the 21 st century: Preference Theory. Oxford: Oxford University Press.

King, Leslie. 2002. Demographic trends, pronatalism, and nationalist ideologies in the late twentieth century. Ethnic and Racial Studies 25 (3), 367-389.

Koivusalo, Meri. 1994. Väestöjaympäristö-ympäristöongelmista ihmisoikeuskysymyksiin ja valtakonflikteihin. In Ollila, Eeva \& Topo, Päivi \& Kajesalo, Kristiina (eds.): Vallaton väestö. Kansallisia ja kansainvälisiä väestöpoliittisia kysymyksiä. Juva: WSOY, 185-212.

Koskinen, Seppo \& Martelin, Tuija \& Notkola, Irma-Leena \& Notkola, Veijo \& Pitkänen, Kari \& Jalovaara, Marika \& Mäenpää, Elina \& Ruokolainen, Anne \& Ryynänen, Markku \& Söderling, Ismo. 2007. Suomen väestö. Helsinki: Gaudeamus.

Kontula, Osmo. 2004. Perhepolitiikka käännekohdassa. Perhebarometri 2004. Katsauksia E 18. Helsinki: Väestöntutkimuslaitos, Väestöliitto.

Lallukka, Seppo. 2003. Venäjän väestökato jatkuu. Tiedonantoja ja katsauksia 2, 1-12.

Larivaara, Meri. 2007. Luottamus potilas-lääkärisuhteessa Pietarissa. In Rotkirch, Anna \& Salmenniemi, Suvi (eds.): Suhteiden Venäjä. Tampere: Gaudeamus.

Malysheva, Marina. 2005. Interview. Moscow 11. May 2005.

Paajanen, Pirjo. 2002. Saako haikara tulla käymään? Suomalaisten lastenhankinnan ihanteet ja todellisuus. Perhebarometri 2002. Katsauksia E 14 / 2002. Helsinki: Väestöntutkimuslaitos.

Paajanen, Pirjo. 2005. Eri teitä vanhemmuuteen - kaksikymmpisenä ja kolmekymppisenä lapsen saaneiden näkemyksiä vanhemmuudesta. Perhebarometri 2005. Katsauksia E 21/2005. Helsinki: Väestöntutkimuslaitos, Väestöliitto.

Palonen, Kari. 1979. Mitä politiikka on? Luonnos politiikan tutkimuksen perusteiksi. Jyväskylän yliopisto, valtio-opin laitos. Julkaisuja, 36.

Perelman Ch \& Olbrecht-Tyteca, L . 1971. The new rhetoric. A treatise on argumentation. London: University of Notre Dame

Pilkington, Hilary. 1994. Russia's youth and its culture. A nation's constructors and constructed. London: Routledge.

Prskawetz, Alexia \& Buber, Isabella \& Sobotka, Tomas \& Engelhardt, Henriette. 2006. Recent changes in family policies in Austria and Germany. In Entre Nous. The European magazine for sexual and reproductive health, WHO 63, 27-29.

Rivkin-Fish, Michele. 2005. Women's Health in Post Soviet Russia. The Politics of Intervention. Bloomington: Indiana Press. 
Rivkin-Fish, Michele. 2006. From “demographic crisis" to "dying nation"- The politics of language and reproduction in Russia. In Goscilo, Helena Lanoux, Andrea (eds.) Gender and national identity in twentieh-century Russian culture. Illinois: Northern Illinois University Press, 151-173.

Rosstat .2004. Российский статистический ежегодник официальное издание 2004. Москва, Федералная служба государственной статистикию.

Rotkirch, Anna. 2000. The Man Question. Loves and Lives in Late 20th Century Russia. University of Helsinki - Department of Social Policy. Research Report

Rotkirch, Anna \& Kesseli, Katja. 2007. "Zona sotsialnogo neblgopoluchija - eto semja s dvumja detmi". Chislo detej i kalendrarj rozhdaemostej peterburgskih zhenshsin. In: Rotkirch, Anna \& Zdravomyslova, Elena (eds.): Novyj byt. St. Petersburg: European University Press.

Rønsen, Marit. 2004. Fertility and Public Policies - Evidence from Norway and Finland. Demographic Research 10: 143-170.

Skortsova, Anna. 2007. Sosiaaliturva Venäjällä, osa 1. Talousmuutosten seuraukset pakottavat sosiaaliturvareformeihin. Tieto\&Trendit 14(4-5):75-78.

Summa, Hilkka. 1989. Hyvinvointipolitiikka ja suunnitteluretoriikka: Tapaus asuntopolitiikka. Yhdyskuntasuunnittelun täydennyskoulutuskeskuksen julkaisuja A 17.Teknillinen korkeakoulu, Espoo.

Statistic Finland. Available on Internet http://www.tilastokeskus.fi

Therborn, Göran. 2004. Between Sex and Power. Family in the World 1900-2000. London: Routledge.

Thornton, Arland \& Philipov Dimiter. 2007. Developmental idealism and family and demographic change in Central and Eastern Europe. European Demographic Research Papers 2007 (3). Vienna: Vienna Institute of Demography, Austrian Academy of Sciences.

Vishenevsky, Anatoly. 1996. Family, fertility, and demographic dynamics in Russia: Analysis and forecast. Russia's Demogrpahic "Crisis". Julie Da Vanzo (eds.): Santa Monica: RAND. http://www.rand.org/publications/CF/CF 124 26.6.2002

Vitali, Agnese \& Billari, Francesco C \& Prskawetz, Alexia \& Testa, Maria Rita .2007. Preference theory and low fertility: A comparative Perspective. European Demographic Research Papers 2007 (2).

World Bank. 2005. Russian Federation: Reducing poverty through growth and social policy reform. Report No. 28923-RU. Poverty Reduction and Economic Management Unit, Europe and Central Asia Region.

Zakharov, Sergei. 1996. Russia's Demographic "Crisis". http://www.rand.org Zdravomyslova, Elena. 1996. Problems of becoming a housewife. In Haavio-Mannila, Elina \& Rotkirch, Anna (eds.): Women's Voices in Russia Today. Aldershot: Darthmouth, 33-48. 